\title{
The novel serine protease PreR-Co promotes endothelium- independent vasorelaxation in rabbit aortic rings
}

\author{
MARÍA PERAL DE BRUNO, ${ }^{1}$ PAULA A. VINCENT, ${ }^{2}$ LILIANA ROMANO ${ }^{1}$ \\ D. CECILIA GUARDIA, ${ }^{2}$ ALFREDO COVIELLO, ${ }^{2}$ AND EDUARDO DE VITO ${ }^{2}$ \\ ${ }^{1}$ Departamento Biomédico, Facultad de Medicina, and ${ }^{2}$ Instituto Superior de \\ Investigaciones Biológicas, Consejo Nacional de Investigaciones Científicas y Técnicas, \\ Universidad Nacional de Tucumán, San Miguel de Tucumán 4000, Argentina
}

Submitted 6 September 2001; accepted in final form 24 September 2002

\begin{abstract}
Peral de Bruno, María, Paula A. Vincent, Liliana Romano, D. Cecilia Guardia, Alfredo Coviello, and Eduardo De Vito. The novel serine protease PreR-Co promotes endothelium-independent vasorelaxation in rabbit aortic rings. Am J Physiol Heart Circ Physiol 284: H704-H710，2003. First published September 26, 2002; 10.1152/ajpheart.00792.2001. - The effect of a novel enzyme (PreR-Co) that activates renal prorenin was studied on rabbit aortas with and without endothelium. It was tested 1) in the basal tone of nonstimulated or ANG II-sensitized rings or rings precontracted with norepinephrine (NE), $\mathrm{PGF}_{2 \alpha}$, high $\mathrm{KCl}$ concentration, and 2) in rings pretreated with enalaprilat, losartan, PD-123319, $N^{\omega}$-nitro-L-arginine methyl ester, HOE-140, indomethacin, or serine protease inhibitors (PMSF, aprotinin, or soybean trypsin inhibitor); kallilkrein and bradykinin were also tested in ANG II-sensitized rings. PreR-Co produced a vasorelaxant effect in the basal tone and in the precontracted rabbit aorta. The effect was endothelium independent, potentiated by endothelium removal or nitric oxide (NO) synthase inhibition, and abolished by boiling the enzyme. In addition, the effect improved when basal tone was increased in ANG II-sensitized aortic rings or in precontracted vessels. No activation of the ANG II, bradykinin, prostaglandin, or NO pathway mediating the PreR-Co response could be obtained, suggesting a direct action of the enzyme. This action seems to be dependent on esterasic activity because serine protease inhibitors like PMSF and aprotinin were able to block the vasorelaxant effect of PreR-Co.

renin activators; vasorelaxant activity; rabbit aorta
\end{abstract}

THE RENIN-ANGIOTENSIN SYSTEM (RAS) has been involved in the modulation of vascular tone. Its action is accomplished by a complex mechanism that involves interactions with several systems in the circulation and in the arterial wall (endothelium and smooth muscle). Local endothelium relaxing factors like nitric oxide (NO), prostacyclin, arachidonic acid vasodilator metabolites, and EDHF and endothelium contractile factors like endothelin, thromboxane $\mathrm{A}_{2}$, and $\mathrm{PGH}_{2}$ have been described $(8,11,20,26,35)$. The balance of these systems as well as other factors are responsible for the regulation of arterial vascular tone. The RAS interacts with

Address for reprint requests and other correspondence: M. Peral de Bruno, Instituto Superior de Investigaciones Biológicas, Balcarce 32, 4000 San Miguel de Tucumán, Argentina (E-mail: mperal@tucbbs.com.ar). kallikrein-kinins through the converting enzyme kininase II (19). Furthermore, demonstrations of all components of the RAS have been reported in the arterial wall $(12,17,22,27,31)$, where ANG II stimulates endothelial synthesis of prostaglandins and lipoxygenase-derived eicosanoids (18) that modulate arterial basal tone. In previous reports, we found that the basal tone of the isolated rabbit aorta was dependent on sensitization by ANG II (23) through activation of $\mathrm{AT}_{1}$ receptors (24).

As early as 1970, De Vito et al. (6) demonstrated that active renin in rat kidney slices originated from an inactive precursor (prorenin). Later on, a novel enzyme, named PreR-Co, which has a $65 \%$ homology with kallikreins and $69 \%$ with serine proteases, was purified to a single electrophoretic band from rat plasma (7). This enzyme activates in vitro inactive tissue renins but not plasma prorenin (33). The presence of considerable amounts of inactive renin in plasma and tissues, which may be converted into relatively small quantities of active renin, has opened the question of its potential functions. Nevertheless, its physiological significance remains unclear.

The objective of this paper was to study whether an enzyme that converts prorenin into active renin in vitro, PreR-Co, has any biological action in the isolated rabbit aorta according to the following hypotheses: 1) by activation of the tissue RAS, because this enzyme activates tissue prorenin but not plasma prorenin; 2) by activation of a kallikrein-kinin pathway, because this enzyme has partial homology with kallikrein; and 3 ) by direct action. These observations were made in the basal tone of nonstimulated or ANG II-sensitized rabbit aortic rings (23-25) and also on hormonally precontracted vascular smooth muscle.

\section{MATERIALS AND METHODS}

\section{Purification of an Activating Renal Prorenin} Plasma Protein

Purification was performed on 24-h plasma from nephrectomized rats as previously described $(7,34)$. In short, plasma

The costs of publication of this article were defrayed in part by the payment of page charges. The article must therefore be hereby marked "advertisement" in accordance with 18 U.S.C. Section 1734 solely to indicate this fact. 
was precipitated with $\left(\mathrm{NH}_{4}\right)_{2} \mathrm{SO}_{4}$, followed by DEAE-cellulose chromatography, gel filtration on Sephacryl S-200 HR, immunoaffinity chromatography, and ion-exchange chromatography using a MonoQ HR-5/5 column associated with a fast-pressure liquid chromatography system and DEAESephadex AP-1 column associated with a high-pressure liquid chromatography system. The active fraction capable of activating inactive kidney renin, named PreR-Co, was dialyzed against distilled water and stored in 50- $\mu$ l aliquots at $-20^{\circ} \mathrm{C}$. Aliquots were mixed in Krebs solution immediately before the experiment. All the experiments on aortic rings were made with a sample of PreR-Co that had been previously tested for its ability to convert prorenin in active renin. Briefly, PreR-Co was tested in rat kidney extract incubated with PreR-Co for $15 \mathrm{~min}$ at $37^{\circ} \mathrm{C}(34)$. The renin concentration was measured by incubation with homologous angiotensinogen and ANG I formed by radioimmunoassay. The same protocol was repeated with samples activated by trypsin (an enzyme that activates prorenin). The PreR-Co concentration used in isolated rabbit aortic rings experiments (1 $\mu \mathrm{g} / \mathrm{ml})$ is $\sim 50$ times lower than the appraised rat plasmatic level $(50 \mu \mathrm{g} / \mathrm{ml})$. Because at the present time there is no available method to measure PreR-Co plasmatic levels, this amount was obtained from the fact that a similar effect of activation was obtained with $100 \mu \mathrm{l}$ of rat plasma as well as with $5 \mu \mathrm{g}$ of enzyme. We point out that the assay was made with rat kidney extract, as described above.

\section{Rabbit Aorta Preparation}

Thoracic aortas from male rabbits (Flanders hybrid, 1.5-2 $\mathrm{kg}$ body weight) were obtained from an authorized dealer. The aorta, carefully cleaned of connective tissue, was immersed in Krebs solution (in mmol/l: $128 \mathrm{NaCl}, 4.7 \mathrm{KCl}, 14.4$ $\mathrm{NaHCO}_{3}, 2.5 \mathrm{CaCl}_{2}, 1.2 \mathrm{NaH}_{2} \mathrm{PO}_{4}, 1.2 \mathrm{MgCl}_{2}, 0.1 \mathrm{Na}_{2^{-}}$ EDTA, and 11.1 glucose). Thereafter, the vessel was transversely cut, yielding rings of 5-mm length. In some experiments, the endothelium was removed by rubbing it with a wire. The rings were fixed in a Lucite chamber to stainless steel wire holders; one holder was anchored to the chamber, whereas the other was attached to an isometric force transducer (Gould UC2) connected to a chart recorder (Kipp and Zonnen BD 41). The chamber contained $7 \mathrm{ml}$ of Krebs solution at $37^{\circ} \mathrm{C}$, pH 7.2 , and bubbled with $95 \% \mathrm{O}_{2}-5 \% \mathrm{CO}_{2}$. In all experiments, rings were equilibrated for 120 min prestretched at a force of $2 \mathrm{~g}$, which was previously found to be the optimal tension for ANG II-induced contraction (23). The experiment began when the baseline tension remained stable while the bath solution was changed every $15 \mathrm{~min}$. The presence or absence of functional endothelium was tested, at the end of the experiment, by assessing the ability of acetylcholine $\left(10^{-6} \mathrm{~mol} / \mathrm{l}\right)$ to relax the previously contracted aortic rings with norepinephrine (NE). After this procedure, the preparation was treated with $100 \mathrm{mmol} / \mathrm{KCl}$.

\section{Protocols}

Protocol 1: effect of PreR-Co on nonstimulated rabbit aortic rings. To test the possible action of PreR-Co on the basal tone of rabbit aortas that had not been exposed before to any vasoactive agent (nonstimulated aortic rings), after a 1-h equilibration period, aortic rings with and without endothelium were treated with PreR-Co in a final bath concentration of $1 \mu \mathrm{g} / \mathrm{ml}$, whereas the paired ring remained as a control.

Protocol 2: effect of ANG II sensitization in the response to PreR-Co. In previous work (23), we demonstrated that sensitization with ANG II induced a novel vasorelaxant action on noncontracted smooth muscle to an endothelium-indepen- dent agent like atrial natriuretic peptide (ANP). Therefore, the objective of the design of the present protocol was to investigate the possible effect of PreR-Co in ANG II-sensitized rabbit aortic rings. Because the vasorelaxant effect of ANP was found to be dependent of increased basal tone (23, 24 ), the present protocol was also performed to test a possible potentiation in the response. Paired aortic rings with or without endothelium were exposed to ANG II $\left(10^{-10}-10^{-5}\right.$ $\mathrm{mol} / \mathrm{l}$ ), obtaining a cumulative dose-response curve (CDRC). The bath was changed each 15 min for $1 \mathrm{~h}$ until ANG II was washed out and the baseline level was totally recovered. At this time, PreR-Co $(1 \mu \mathrm{g} / \mathrm{ml})$ was added and the response was followed for $7 \mathrm{~min}$.

Protocol 3: effect of PreR-Co in precontracted rings. To test the effect of PreR-Co in precontracted smooth muscle, rabbit aortic rings with and without endothelium were exposed to different agents. A NE CDRC $\left(10^{-9}-10^{-5} \mathrm{~mol} / \mathrm{l}\right)$ was obtained. Subsequently, after a stable plateau level was reached, PreR-Co $(1 \mu \mathrm{g} / \mathrm{ml})$ was added to one ring, with the remaining paired ring as a control. The response to PreR-Co in the contracted vessel was followed for $7 \mathrm{~min}$. A similar experiment was carried out using a different agonist, $\mathrm{PGF}_{2 \alpha}$ $\left(10^{-6} \mathrm{~mol} / \mathrm{l}\right)$ or high $\mathrm{KCl}(100 \mathrm{mmol} / \mathrm{l})$, as a contracting agent. The role of endothelium in the response to PreR-Co was further studied in NE-contracted aortas with endothelium treated or not treated with an inhibitor of NO synthase, $N^{\omega}$-nitro-L-arginine methyl ester (L-NAME; $10^{-4} \mathrm{~mol} / \mathrm{l}$ ). To rule out the possible presence of a thermostable vasoactive nonenzymatic compound, the enzyme was tested after it was heated for up to $5 \mathrm{~min}$ in a boiling bath and added $(1 \mu \mathrm{g} / \mathrm{ml})$ to the NE-precontracted vessel.

Protocol 4: effect of inhibitors of the RAS and kinins in the response to PreR-Co. To test the effect of inhibitors at different levels of the RAS on the response to PreR-Co, different compounds were used: an angiotensin-converting enzyme (ACE) inhibitor (enalaprilat) with the purpose of blocking a possible tissue generation of ANG II, and an inhibition of local kinin degradation, because the converting enzyme also has kininase II activity (19). Aortic rings with or without endothelium were treated with ANG II to obtain a CDRC $\left(10^{-10}-10^{-5} \mathrm{~mol} / \mathrm{l}\right)$. After the rings were washed and had recovered to baseline levels (ANG II-sensitized aortas), $10^{-6}$ $\mathrm{mol} / \mathrm{l}$ enalaprilat was added for $15 \mathrm{~min}$ to the aortic bath and PreR-Co $(1 \mu \mathrm{g} / \mathrm{ml})$ was added to both control and treated rings. A similar experiment was carried out using nonpeptidic ANG II receptor antagonists: the $\mathrm{AT}_{1}$ antagonist losar$\tan \left(10^{-5} \mathrm{~mol} / \mathrm{l}\right)$ and the $\mathrm{AT}_{2}$ receptor antagonist $\mathrm{PD}-123319$ $\left(1.36 \times 10^{-5} \mathrm{~mol} / \mathrm{l}\right)$. The objective of this study design was to rule out any action of ANG II in mediating the aortic ring response to PreR-Co.

To test any nonspecific activity of PreR-Co through the release of a vasorelaxant agent related to kinins, a bradyki$\operatorname{nin} \mathrm{B}_{2}$ receptor antagonist $\left[10^{-7} \mathrm{~mol} / \mathrm{l} \mathrm{D}-\mathrm{Arg}-\left(\mathrm{Hyp}^{3}, \mathrm{Thi}^{5}\right.\right.$,D$\mathrm{Tic}^{7}, \mathrm{Qic}^{8}$ )bradykinin (HOE-140)] was added to ANG II-sensitized aortic rings as described above.

Protocol 5: effect of kallikrein and bradykinin on rabbit aortic rings sensitized with ANG II. The hypothesis of a tissular kalllikrein-bradykinin pathway effect in resting basal tone of ANG-II sensitized aortic rings and the possible effect of PreR-Co through its activation was tested using agonists and antagonists of this system. Rabbit aortic rings with or without endothelium were sensitized with ANG II (as described in protocol 2) with the addition of kallikrein (1 $\mu \mathrm{g} / \mathrm{ml})$. A similar experiment was run with bradykinin, and a CDRC $\left(10^{-11}-10^{-6} \mathrm{~mol} / \mathrm{l}\right)$ was obtained in the presence or absence of the $\mathrm{B}_{2}$ receptor antagonist HOE-140 (10 $\left.{ }^{-7} \mathrm{~mol} / \mathrm{l}\right)$. In rabbit aortic rings with endothelium, a CDRC to bradyki- 
$\operatorname{nin}\left(10^{-11}-10^{-6} \mathrm{~mol} / \mathrm{l}\right)$ was also obtained during the plateau of a contraction induced by NE $\left(10^{-5} \mathrm{~mol} / \mathrm{l}\right)$.

Protocol 6: effect of indomethacin on the response to PreRCo. To test whether some cyclooxygenase-derived metabolite was mediating the vasorelaxant effect of PreR-Co, experiments were performed with indomethacin (a cyclooxygenase inhibitor). Paired rabbit ANG II-sensitized aortic rings with endothelium were treated or not treated with indomethacin $\left(10^{-5} \mathrm{~mol} / \mathrm{l}\right)$ for $15 \mathrm{~min}$, and, thereafter, PreR-Co $(1 \mu \mathrm{g} / \mathrm{ml})$ was added. A similar protocol was carried out in NE-precontracted vessels.

Protocol 7: effect of serine protease inhibitors on the response to PreR-Co. Aortic rings with endothelium were treated with different serine protease inhibitors: plasma [1 $\mu \mathrm{g} / \mathrm{ml}$ soybean trypsin inhibitor (SBTI)] and tissue kallikrein inhibitors ( $1 \mu \mathrm{g} / \mathrm{ml}$ aprotinin) or a nonspecific serine protease inhibitor ( $1 \mu \mathrm{g} / \mathrm{ml}$ PMSF). Each inhibitor was added for 15 min to the aortic bath to nonstimulated or ANG II-sensitized aortic rings. Afterward, PreR-Co $(1 \mu \mathrm{g} / \mathrm{ml})$ was added to both the control and treated samples.

To rule out the possibility that inhibitors added to the bath did not have enough time to inactivate the enzyme before their interaction with the aortic tissue, another series of experiments were performed. PreR-Co $(100 \mu \mathrm{g} / \mathrm{ml})$ was incubated for 15 min in Ringer solution (control) or with PMSF $(0.1$ or $0.48 \mathrm{mg} / \mathrm{ml})$, SBTI $(0.1$ or $1.0 \mathrm{mg} / \mathrm{ml})$, or aprotinin $(0.1$ or $2.0 \mathrm{mg} / \mathrm{ml}$ ), and, after that, $70 \mu \mathrm{l}$ of the incubating solution were added to $7 \mathrm{ml}$ of the bathing solution containing the aortic ring (final concentration of PreR-Co was $1 \mu \mathrm{g} / \mathrm{ml}$ ). The higher concentrations were selected because they have been proved to be effective on prorenin activation (34). The lower concentrations of inhibitors were in the range of those of PreR-Co producing a vasorelaxant effect. Because the PreR-Co vasorelaxant effect is greater in the precontracted aortic ring, experiments with simultaneous incubation of PreR-Co and inhibitors were performed by adding the enzyme at the plateau of a NE contraction.

\section{Chemicals}

Human ANG II, NE (DL-arterenol), acetylcholine bromide, indomethacin, kallikrein, bradykinin, HOE-140, SBTI, phenylmethylsulfonyl fluoride (PMSF), and aprotinin were purchased from Sigma Chemical (St. Louis, MO). Enalaprilat (Lotrial) was from Roemmers. Losartan was a gift from Dr. Ronald Smith (Merck). PD-123319 (P-186) was obtained from Research Biochemicals (Natick, MA). L-NAME was a gift from Dr. Alberto Nasjletti (New York Medical College, Valhalla, NY).

\section{Analysis of Results}

The results, expressed as means $\pm \mathrm{SE}$, were analyzed by Student's $t$-test to compare paired and unpaired averages. When more than two means were compared, ANOVA and the Newman-Keuls test were used when appropriate. The statistical program chosen was GraphPad Prism (GraphPad Software, San Diego, CA), and the level of significance established was $P<0.05$

\section{RESULTS}

Figure 1 shows records of a typical experiment with the relaxing effect of PreR-Co $(1 \mu \mathrm{g} / \mathrm{ml})$ in rabbit aortic rings without endothelium on the basal tone of a nonANG II-sensitized ring $(A)$, on the basal tone of a previously ANG II-sensitized ring $(B)$, and on the plateau of a NE-contracted ring $(C)$. In all cases, the tensions of aortic rings declined immediately in the

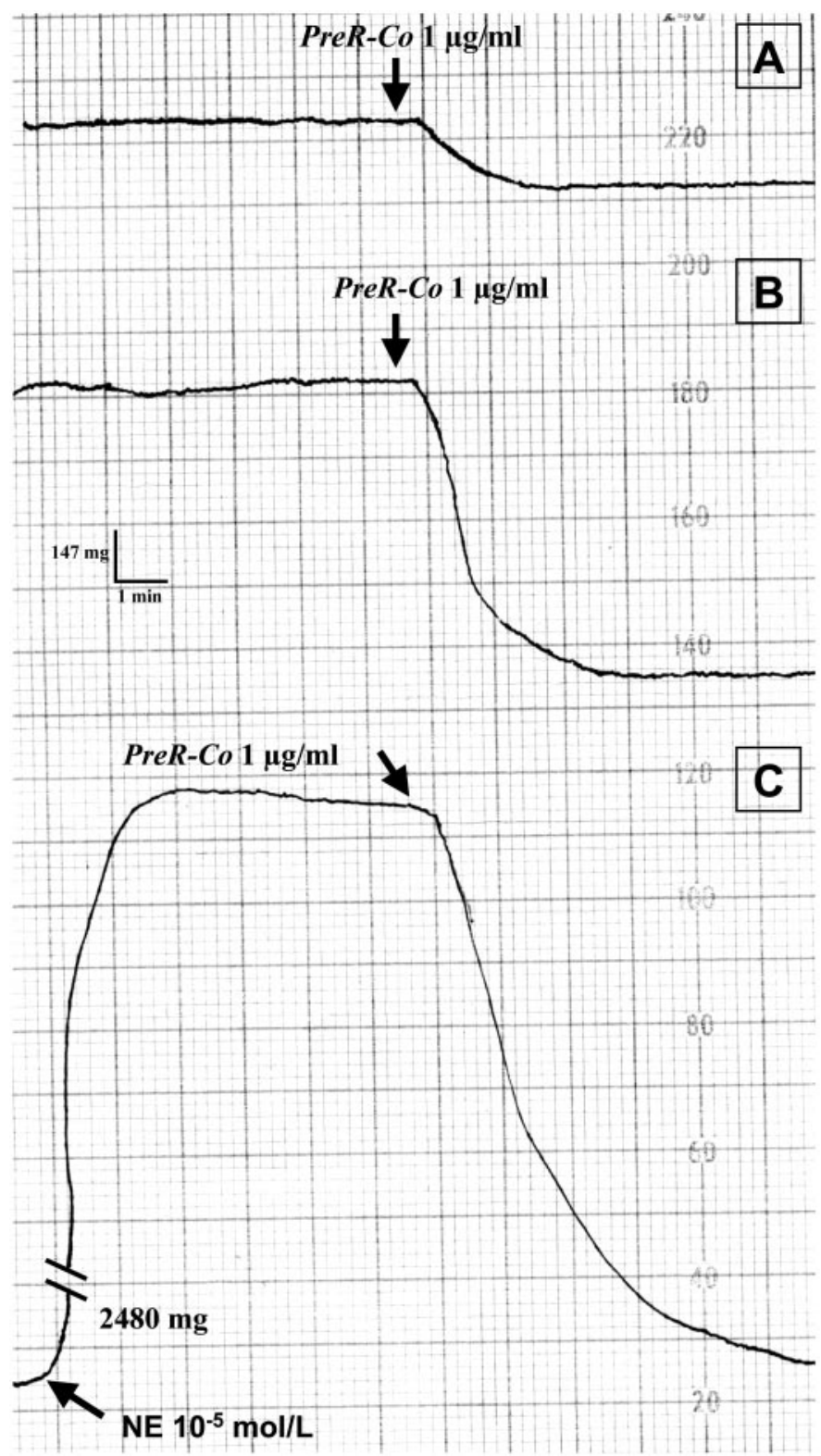

Fig. 1. Graphic recordings of a typical experiment showing the response to PreR-Co $(1 \mu \mathrm{g} / \mathrm{ml})$ of rabbit aortic rings without endothelium. $A$ : basal tone of a non-ANG II-sensitized ring; $B$ : basal tone of a sensitized ANG II sample; $C$ : plateau of a norepinephrine (NE)-contracted ring.

presence of PreR-Co. In aortic rings with endothelium, the mean fall produced by PreR-Co on the basal tone of nonstimulated rings was $101 \pm 44 \mathrm{mg}(n=13)$, whereas it was $327 \pm 105 \mathrm{mg}(n=16)$ in ANG IIsensitized rings and $1,916 \pm 561 \mathrm{mg}(n=7)$ in the NE-contracted rings. The effect was reversible because, after washout, the aortic ring recovered its contractility to NE. In another experiment using a different agonist $\left(10^{-6} \mathrm{~mol} / / \mathrm{PGF}_{2 \alpha}\right)$, a similar vasorelaxant effect of PreR-Co was obtained in the precontracted vessels.

When a sample of PreR-Co was placed for 5 min in a boiling water bath, no relaxant effect in NE-precontracted aortic rings with endothelium was observed 
(mean fall of $16 \pm 14 \mathrm{mg}, n=5$, in boiled samples vs. $1,038 \pm 250 \mathrm{mg}, n=6$, in nonboiled samples). No significant difference in the contractile response to high $\mathrm{KCl}$ in the absence or presence of PreR-Co was obtained (developed tension of 4,952 $\pm 880 \mathrm{mg}, n=7$, and 4,489 $\pm 860 \mathrm{mg}, n=7$, respectively).

Figure 2 shows the response of PreR-Co on aortic rings with and without endothelium and sensitized or not sensitized with ANG II. Sensitized aortic rings without endothelium significantly increased the response to PreR-Co when compared with those rings not sensitized to ANG II $(P<0.01)$. This potentiation could not be obtained in the presence of endothelium. The role of endothelium in the response to PreR-Co was further studied in NE-contracted unrubbed aortas treated or not treated with L-NAME $\left(10^{-4} \mathrm{~mol} / \mathrm{l}\right)$. The mean vasorelaxant effect of PreR-Co was $707 \pm 89 \mathrm{mg}$ in untreated aortas $(n=5)$, whereas in the L-NAME-treated pair it was $2,705 \pm 663 \mathrm{mg}(n=7, P<0.03$, unpaired $t$-test).

The effect of PreR-Co in the basal tone of ANG IIsensitized aortic rings with endothelium was not significantly modified by either pretreatment with the ACE inhibitor enalaprilat or the $\mathrm{AT}_{1}$ receptor antagonist losartan. The mean fall with $1 \mu \mathrm{g} / \mathrm{ml}$ PreR-Co of arteries with endothelium pretreated with enalaprilat $\left(10^{-6}\right.$ $\mathrm{mol} / \mathrm{l})$ was $356 \pm 156 \mathrm{mg}(n=6)$, not significant with respect to the nontreated control $(327 \pm 125 \mathrm{mg}, n=16$, unpaired $t$-test). The absence of endothelium did not modify the lack of response to the ACE inhibitor (data not shown). Figure 3 shows that losartan $\left(10^{-5} \mathrm{~mol} / \mathrm{l}\right.$, an ANG II $\mathrm{AT}_{1}$ receptor antagonist) was unable to modify the vasorelaxant effect of PreR-Co $(1 \mu \mathrm{g} / \mathrm{ml})$ on the basal tone of ANG II-sensitized aortic rings both with and without endothelium. Furthermore, the potentiation of the PreR-Co vasorelaxant effect by the absence of endo-

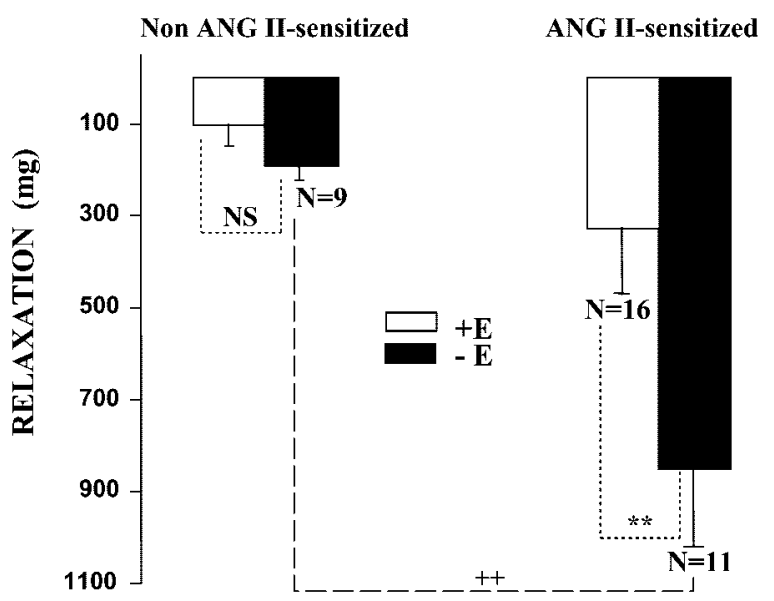

Fig. 2. Effect of PreR-Co $(1 \mu \mathrm{g} / \mathrm{ml})$ on the basal tone of noncontracted rabbit aortas with and without previous sensitization with ANG II. No difference was found in the PreR-Co effect on rings with endothelium $(+\mathrm{E})$ vs. those without endothelium $(-\mathrm{E})$ in nonsensitized aortic rings, whereas the effect was significant in ANG II-sensitized rings $(* * P<$ 0.01 , paired Student's $t$-test). No difference was found when comparing the effect of PreR-Co on non-ANG II-sensitized rings vs. sensitized rings with endothelium, whereas it was significant in the rings without endothelium $(++P<0.01$, ANOVA and Newman-Keuls test). Means \pm SE are indicated; $n$, number of experiments. NS, not significant.

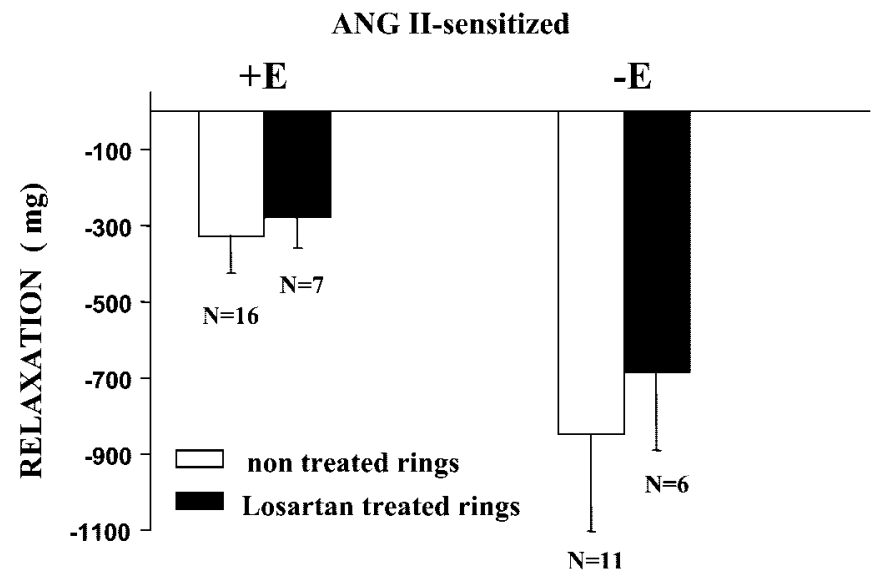

Fig. 3. The effect of losartan $\left(10^{-5} \mathrm{~mol} / \mathrm{l}\right)$ was proven in rabbit aortas previously sensitized with ANG II. No significant difference was found in the vasorelaxant action of PreR-Co $(1 \mu \mathrm{g} / \mathrm{ml})$ on rings with and without endothelium. No difference was found when comparing the effect of PreR-Co on losartan-treated vs. nontreated rings (NS, paired Student's $t$-test). Means $\pm \mathrm{SE}$ are indicated.

thelium was also present in losartan-treated vessels $(P<$ 0.05). PD-123319 $\left(1.36 \times 10^{-5} \mathrm{~mol} / \mathrm{l}\right.$, an ANG II $\mathrm{AT}_{2}$ receptor antagonist) was also unable to modify the vasorelaxant effect of PreR-Co $(1 \mu \mathrm{g} / \mathrm{ml})$, which added during the plateau of NE-contracted rings with endothelium. Mean relaxation was 2,358 $\pm 367 \mathrm{mg}$ in the control rings $(n=6)$ and $2,238 \pm 450 \mathrm{mg}$ in the experimental samples ( $n=4$, not significant, unpaired $t$-test).

To test whether the PreR-Co relaxing effect is mediated by kininogenasic activity releasing endogenous bradykinin, kallikrein and bradykinin were tested in ANG II-sensitized aortic rings. Kallikrein $(1 \mu \mathrm{g} / \mathrm{ml})$ did not show any effect on aortic rings. A CDRC for bradykinin $\left(10^{-11}-10^{-6} \mathrm{~mol} / \mathrm{l}\right)$ showed only a contracting effect that was obtained with concentrations over $10^{-9} \mathrm{~mol} / \mathrm{l}$, and no difference was obtained in the absence of endothelium (Fig. 4). The contractile effect of bradykinin in arteries with endothelium was not modified by pretreatment with HOE-140 $\left(10^{-7} \mathrm{~mol} / \mathrm{l}\right)$. In addition, no activity of bradykinin was obtained in NE-precontracted vessels. In another series of experiments, no effect of HOE-140 $\left(10^{-7}\right.$ $\mathrm{mol} / \mathrm{l}$ ) was obtained in the vasorelaxant effect of PreR-Co $(1 \mu \mathrm{g} / \mathrm{ml})$ in ANG II-sensitized aortas with endothelium (188 $\pm 61 \mathrm{mg}, n=5$, in the control vs. $176 \pm 54 \mathrm{mg}, n=$ 5 , with HOE-140, not significant, unpaired $t$-test). The vasorelaxant activity of PreR-Co $(1 \mu \mathrm{g} / \mathrm{ml})$ was not modified by pretreatment with indomethacin $\left(10^{-5} \mathrm{~mol} / \mathrm{l}\right)$ in NE-precontracted rings with endothelium, as shown in Fig. 5.The effect of PreR-Co $(1 \mu \mathrm{g} / \mathrm{ml})$ on the basal tone in ANG II-sensitized and nonsensitized aortic rings with endothelium was not modified by pretreatment with SBTI $(1 \mu \mathrm{g} / \mathrm{ml})$, PMSF $(1 \mu \mathrm{g} / \mathrm{ml})$, or aprotinin $(1 \mu \mathrm{g} / \mathrm{ml})$. The effect of PreR-Co on ANG II-sensitized arteries was $327 \pm 125 \mathrm{mg}(n=16)$, which was not modified by pretreatment with SBTI ( $337 \pm 153 \mathrm{mg}, n=5)$, aprotinin (391 $\pm 90 \mathrm{mg}, n=5)$, and PMSF $(261 \pm 150 \mathrm{mg}, n=5)$ (not significant, ANOVA post test with Newman-Keuls). Similar results were obtained in nonstimulated aortic rings (data not shown). The vasorelaxant effect of 


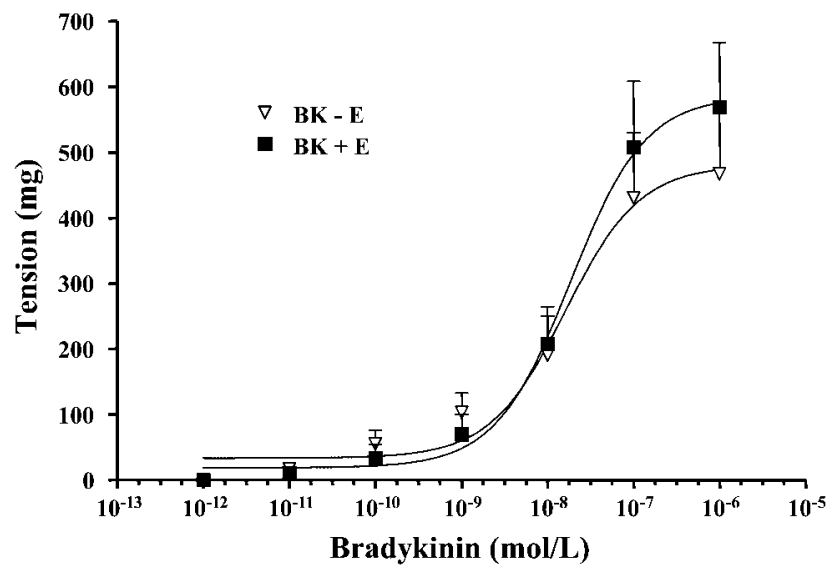

Fig. 4. The effect of bradykinin (BK; $10^{-12}-10^{-5} \mathrm{~mol} / \mathrm{l}$ ) was proven by a cumulative dose-response curve (CDRC) in rabbit aortas with endothelium previously sensitized with ANG II. Only a contractile effect was obtained with higher concentrations, and no significant difference was found between the CDRC with and without endothelium (NS, ANOVA and Newman-Keuls test). Means \pm SE are indicated; $n=8$.

PreR-Co was inhibited when the enzyme was preincubated with PMSF or aprotinin before being added to the bath containing the aortic ring. This inhibition was dose dependent (Fig. 6). However, SBTI, even in the highest concentration, produced nonsignificant inhibition (Fig. 6).

\section{DISCUSSION}

The present results demonstrate for the first time that 1) PreR-Co, an enzyme that converts inactive prorenin in active renin, relaxes isolated aortic rabbit smooth muscle; 2 ) this relaxation is improved when the vascular basal tone is increased and the vessels are precontracted; 3 ) the relaxing response is endothelium independent and potentiated by the removal of endothelium or inhibition of NO synthase; 4) the relaxing response appears not to be mediated by any autacoid pathway receptor, supporting the view of a direct action of PreR-Co; 5) this dilator action was dependent on esterase activity and blocked by the serine protease inibitors PMSF and aprotinin; and 6 ) the concentration of PreR-Co producing a vasorelaxant effect in aortic rings is $\sim 50$ times lower than that converting in vitro rat prorenin into active renin. The vasorelaxant effect in nonstimulated aortic basal tone is very small, but it is greatly increased in previously ANG II-sensitized rabbit aortas. This result is analogous to that previously demonstrated in our laboratory (23-25) with ANP. In addition, the PreR-Co relaxing effect is largely increased in NE- or $\mathrm{PGF}_{2 \alpha}$-precontracted rings. Nevertheless, it is difficult at present to define the mechanism by which PreR-Co promotes the vasorelaxant action. The presence of a thermostable nonenzymatic vasoactive compound associated with PreR-Co was discounted by the fact that the vasorelaxant response was abolished after the sample was placed for a few minutes in a boiling water bath. PreR-Co is a novel enzyme whose biological actions are unknown. In an earlier study from this laboratory, we demonstrated that
PreR-Co promotes the activation of tissular prorenin to renin in vitro $(7,33)$ and, furthermore, that it does not cleave active renin or angiotensinogen. The lack of a constrictor effect of PreR-Co may also be due to low availability of the enzyme substrate prorenin in the rabbit aortic wall and the inability of PreR-Co to cleave plasma prorenin compared with renal tissue prorenin (7, 33). The extrarenal prorenins, aortic and plasma, would be insensitive to the enzymatic action of PreRCo. Prorenin is a heterogeneous protein, mainly due to variable glycosylation (14). Moreover, it is not entirely proven that inactive renin in the kidney has an identical configuration as that in circulating plasma (34). This concept could be extended to other fluids and tissues, including the aorta (33). Neither ACE inhibi-
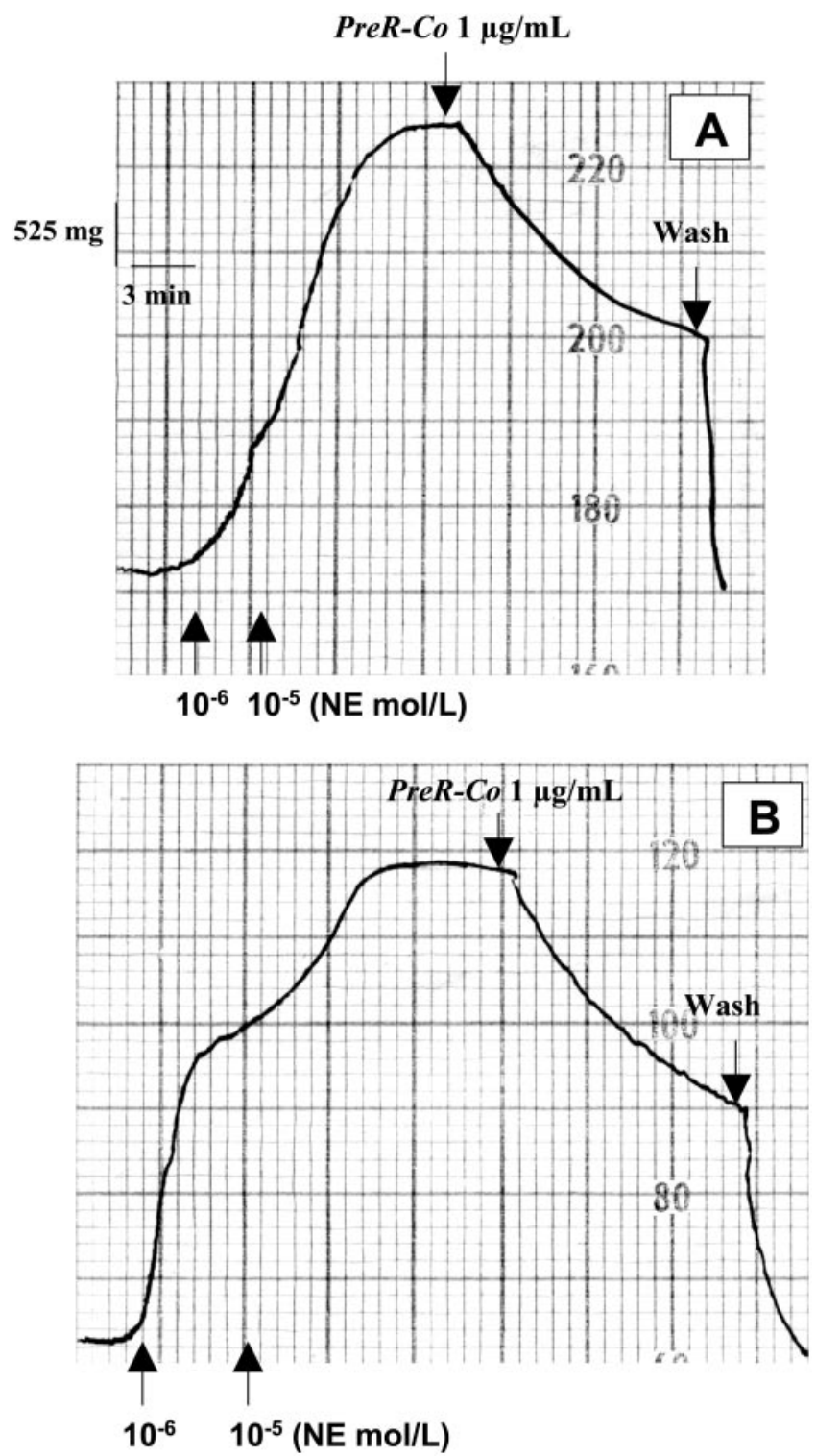

Fig. 5. Graphic recording of a typical experiment showing the response to PreR-Co $(1 \mu \mathrm{g} / \mathrm{ml})$ in NE-precontracted rabbit aortic rings with endothelium. Rings were not pretreated $(A)$ or pretreated $(B)$ with indomethacin $\left(10^{-5} \mathrm{~mol} / \mathrm{l}\right)$. Both recordings show a vasorelaxation promoted by PreR-Co independent of the prostanoid inhibition. 


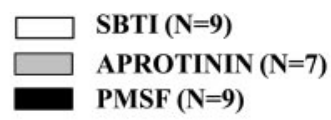

Doses $(\mathrm{mg} / \mathrm{ml})$
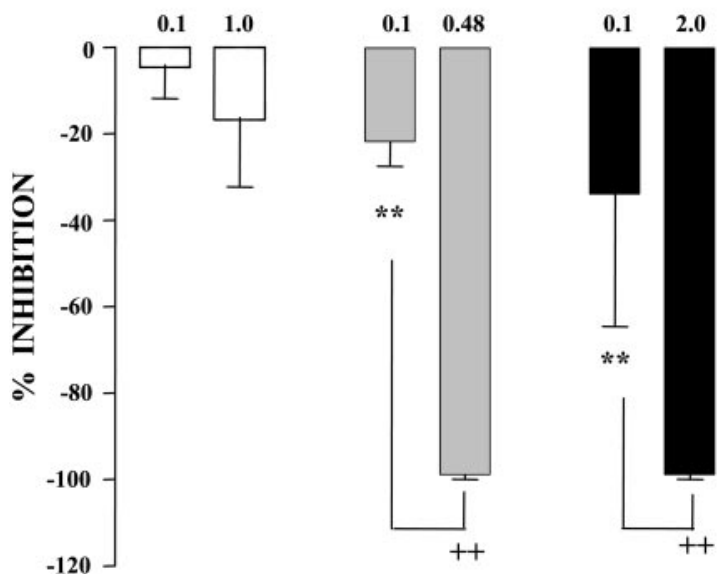

Fig. 6. Effect of inhibitors of serine proteases on the vasorelaxant action of PreR-Co in NE-precontracted aortic rings without endothelium. The bars represent the percent inhibition of the effect of PreR-Co. PreR-Co $(100 \mu \mathrm{g} / \mathrm{ml})$ was incubated with lower and higher doses of soybean trypsin inhibitor (SBTI; 0.1 and $1 \mathrm{mg} / \mathrm{ml}$ ), aprotinin $(0.1$ and $0.48 \mathrm{mg} / \mathrm{ml})$, or PMSF $(0.1$ and $2 \mathrm{mg} / \mathrm{ml}$ ) before the addition of the enzyme to the bath containing the aortic ring. The final concentration of PreR-Co in the aortic bathing solution was $1 \mu \mathrm{g} / \mathrm{ml}$. No significant inhibition of lower and higher doses of SBTI was found on the vasorelaxant effect of PreR-Co. On the other hand, a significant dose-dependent inhibition by PMSF and aprotinin was found with higher doses $(++P<0.01$, ANOVA and Newman-Keuls test). A significant difference was found when comparing the effect of lower and higher doses of PMSF and aprotinin $(* * P<0.01$, paired Student's $t$-test). Means $\pm \mathrm{SE}$ are indicated.

tors nor $\mathrm{AT}_{1}$ or $\mathrm{AT}_{2}$ receptor blockers inhibited the vasorelaxant response to PreR-Co. This would indicate the absence of a vasoconstrictor counterbalancing effect through the release of local ANG II, suggesting that another mechanism independent of prorenin to renin activation is involved. The hypothesis of a vasorelaxant effect through other peptides of the angiotensin family having vasodilator properties, like ANG(1-7) $(1,9)$, ANG IV $(3,4)$, and ANG-(3-7) $(15)$, is a tenuous explanation, because, although vasorelaxant action has been demonstrated, their effects are endothelium dependent and mediated by $\mathrm{NO}$ or bradykinin. Furthermore, in rabbit aortic rings, ANG-(1-7) lacks vasorelaxant activity, and it behaves as an $\mathrm{AT}_{1}$ receptor antagonist of ANG II (21). Because PreR-Co also has kininogenase activity and a 65\% homology with kallikreins (34), a different hypothesis was examined to assess whether the vasorelaxant effect could be mediated by kinins. However, this hypothesis was ruled out because no relaxant or contracting effect was observed when kallikrein was tested in the rabbit aorta ring preparation, probably because there is not enough local substrate available (kininogen). Furthermore, bradykinin had no relaxing effects but only a contractile action in our ANG II-sensitized rabbit aortic rings, a fact that is in agreement with a previous report (29) in precontracted vessels. In addition, the available data demonstrate that only $\mathrm{B}_{1}$ but not $\mathrm{B}_{2}$ receptors are present in the rabbit aorta (30). Thus it was expected that HOE-140 (a $\mathrm{B}_{2}$ receptor blocker) did not inhibit either the bradykinin or PreR-Co response.

The possibility that $\mathrm{NO}$ or a vasorelaxant prostanoid acts as a mediator of the effect of PreR-Co seems unlikely because removal of endothelium, NO synthase inhibition, or indomethacin treatment did not abolish the vasorelaxant response. On the contrary, in aortic rings without endothelium or L-NAME treatment, the vasorelaxant effect of PreR-Co was potentiated. In addition, the rabbit aorta is considered a bioassay relatively insensitive to prostacyclin $(10,13)$. The potentiation by disruption of endothelium may result in an increase of basal tone produced by the lack of a counterregulatory endogenous vasodilator like NO (28). Despite the fact that several contractile and vasodilator prostanoids have been described (18), most of them are endothelium dependent. Nevertheless, it has been recently reported that a prostanoid derivative from eicosapentaenoic acid may produce a vasorelaxant effect in Wistar-Kyoto rat aortas without endothelium (8). This possibility was ruled out because pretreatment with indomethacin was unable to inhibit the PreR-Co action. Recent reports $(2,16)$ have demonstrated that a hyperpolarizing factor derived from the endothelium regulate $\mathrm{K}^{+}$channels in vascular smooth muscle (like coronary arteries), producing their opening and a consequent hyperpolarization that results in smooth muscle relaxation. The present results show that PreR-Co was devoid of any significant relaxing effect on high $\mathrm{KCl}$-contracted rabbit aortas. Therefore, we assume that PreR-Co or its released metabolite has to produce the relaxing effect from the existence of a minimum level of resting transmembrane potential. However, in the high KCl-contracted vessel, this potential disappears because of the lack of outward diffusion of potassium, secondary to the abolition of the outward/inward concentration difference $(5,32)$.

All of the above findings appear to support the view that the relaxing response to PreR-Co is not mediated by any autacoid pathway receptor. In addition, the mechanism of the vasorelaxant action of PreR-Co appears to be independent of the tissue prorenin conversion or of any product from the RAS or kallikrein system. The present results clearly show that effect of PreR-Co seems to be associated with its esterasic activity because it was abolished by pretreatment with PMSF (a nonspecific serine protease inhibitor) and aprotinin. It is interesting to point out that there is a difference in the enzymatic activity according to the plasma or tissular substrate. We pointed out above the difference between plasma and renal prorenin (34). At present, we do not know how the inhibitors act with PreR-Co. The first hypothesis of an interaction of serine protease inhibitors with the substrate may be ruled out because PreR-Co was inactivated before its exposure to the vascular tissue. Therefore, it is more probable that the action of inhibitors may be due to an interaction on the active site of the enzyme PreR-Co. In any case, it is necessary to point out that the enzymatic 
activity is required for PreR-Co vasorelaxation. It is appropriate to emphasize that the present results show for the first time that an enzyme that activates renal prorenin by an unknown esterase activity produces a vasorelaxant effect in basal tone and precontracted rabbit aortic rings. This finding invites speculation that PreR-Co may have physiological action as a modulator of vascular smooth muscle tone. Because its vasorelaxant effect is greater when the vascular tone is increased, it may have a role in different forms of hypertension characterized by elevated vascular basal tone $(18,28)$. Clarification of the precise mechanism requires further investigation.

The kind suggestions of Dr. Alberto Nasjletti (New York Medical College, Valhalla, New York) are fully recognized.

This study was funded by Consejo Nacional de Investigaciones Científicas y Técnicas de la República Argentina Grant PIP-9007 and by Consejo de Investigaciones de la Universidad Nacional de Tucumán Proyectos 26/I106 and 26/D112.

\section{REFERENCES}

1. Brosnihan KB, Li P, Tallant EA, and Ferrario CM. Angiotensin-(1-7): a novel vasodilator of the coronary circulation. Biol Res 31: 227-234, 1998.

2. Campbell WB, Gebremedhin D, Pratt PF, and Harder DR. Identification of epoxyeicosatrienoic acids as endothelium-derived hyperpolarizing factors. Circ Res 78: 415-423, 1996.

3. Chen S, Patel JM, and Block ER. Angiotensin IV-mediated pulmonary artery vasorelaxation is due to endothelial intracellular calcium release. Am J Physiol Lung Cell Mol Physiol 279: L849-L856, 2000.

4. Cheng DY, De Witt BJ, Dent EL, Nossaman BD, and Kadowitz PJ. Analysis of responses to angiotensin IV in the pulmonary vascular bed of the cat. Eur J Pharmacol 261: 223-227, 1994.

5. Cox RH, Folander K, and Swanson R. Differential expression of voltage-gated $\mathrm{K}^{+}$channel genes in arteries from spontaneously hypertensive and Wistar-Kyoto rats. Hypertension 37: 1315-1322, 2001.

6. De Vito E, Cabrera RR, and Fasciolo JC. Renin production and release by rat kidney slices. Am J Physiol 219: 1042-1045, 1970.

7. De Vito E, Guardia DC, and Martinez de Melián ER. Activation of inactive renal renin by nephrectomized and non-nephrectomized rat plasma. A novel enzymatic mechanism of renin activation? Comp Biochem Physiol 113B: 433-438, 1996.

8. Engler MB, Engler MM, Browne A, Sun YP, and Sievers R. Mechanisms of vasorelaxation induced by eicosapentaenoic acid (20:5n-3) in WKY aorta. Br J Pharmacol 131: 1793-1799, 2000.

9. Feterik K, Smith L, and Katusic ZS. Angiotensin-(1-7) causes endothelium-dependent relaxation in canine middle cerebral artery. Brain Res 873: 75-82, 2000.

10. Forstermann U, Herting G, and Neufang B. The importance of endogenous prostaglandins other than prostacyclin for the modulation of contractility of some rabbit blood vessels. $\mathrm{Br} J$ Pharmacol 81: 623-630, 1984.

11. Furchgott RF and Zawadski JV. The obligatory role of endothelial cells in the relaxation of arterial smooth muscle by acetylcholine. Nature 288: 373-376, 1980.

12. Gohlke $\mathbf{P}$, Bunning $\mathbf{P}$, and Unger $\mathbf{T}$. Distribution and metabolism of angiotensin I and II in the blood vessel wall. Hypertension 20: 151-157, 1992

13. Hardhazy P, Malomvolgyi B, and Magyar K. Differential contractile responsiveness of isolated rabbit arteries from different vascular beds to cyclo-oxygenase inhibitors and $\mathrm{PGI}_{2}$. Eur $J$ Pharmacol 98: 323-330, 1984.

14. Khalidi N, McKenzie I, and McKenzie JK. Isoelectric heterogeneity of human prorenin (inactive renin) in body fluids. $A m J$ Hypertens 4: 56-59, 1999.
15. Kuziema-Leska M, Car H, and Wisniewski K. Effect of bicuculline and angiotensin II fragment 3-7 on learning and memory processes in rats chronically treated with ethanol. Pol $J$ Pharmacol 50: 15-22, 1998.

16. Li PL, Zou AP, and Campbell WB. Regulation of potassium channels in coronary arterial smooth muscle by endotheliumderived vasodilator. Hypertension 29: 262-267, 1997.

17. Lilly LS, Pratt RE, Alexander RW, Larson DM, Ellison KE, Gimbrone MA Jr, and Dzau VJ. Renin expression by vascular endothelial cells in culture. Circ Res 57: 312-318, 1985.

18. Lin L and Nasjletti A. Role of endothelium-derived prostanoids in angiotensin-induced vasoconstriction. Hypertension 18: 158$164,1991$.

19. Linz W, Wiemer G, Gohlke P, Unger T, and Scholkens BA. Contribution of kinins to the cardiovascular actions of angiotensin-converting enzyme inhibitors. Pharmacol Rev 47: 25-49, 1995.

20. Lüscher TF. Imbalance of endothelium-derived relaxing and contracting factors. Am J Hypertens 3: 317-330, 1990.

21. Mahon JM, Carr RD, Nicol AK, and Henderson IW. Angiotensin-(1-7) is an antagonist at the type 1 angiotensin II receptor. J Hypertens 12: 1377-1381, 1994.

22. Mizuno K, Tani M, Niimura S, Hashimoto S, Satoh A, Shimamoto K, Inagami T, and Fucuchi S. Direct evidence for local generation and release of angiotensin II in human vascular tissue. Biochem Biophys Res Commun 165: 457-463, 1989.

23. Peral de Bruno M, Coviello A, Meyer M, and Forssmann WG. Relaxation of non-contracted smooth muscle by atrial natriuretic peptide. Clin Exp Hypertens 14: 1125-1139, 1992.

24. Peral de Bruno M, Romano L, and Coviello A. Losartan reduces the vasorelaxant effect of atrial natriuretic peptide on basal tone in aorta. Clin Exp Hypertens 21: 1257-1271, 1999.

25. Peral de Bruno M, Romano L, Proto M, and Coviello A. Atrial natriuretic peptide relaxes arterial basal tone induced by coarctation hypertension. Peptides 20: 485-491, 1999.

26. Pfister SL, Spitzbarth N, Nithipatikom K, Edgemond WS, Falck JR, and Campbell WB. Identification of the 11,14,15and 11,12,15-trihydroxyeicosatrienoic acids as endothelium-derived relaxing factors of rabbit aorta. J Biol Chem 273: 38793887, 1998.

27. Phillips MI, Speakman EA, and Kimura B. Levels of angiotensin and molecular biology of the tissue renin angiotensin systems. Regul Pept 42: 1-20, 1993.

28. Pucci ML, Miller KB, Dick LB, Guan H, Lin L, and Nasjletti A. Vascular responsiveness to nitric oxide synthesis inhibition in hypertensive rats. Hypertension 23: 744-751, 1994.

29. Regoli D, Mizrahi J, D'Orleans-Juste P, and Caranikas S. Effects of kinins on isolated blood vessels. Role of endothelium. Can J Physiol Pharmacol 60:1580-1583, 1982.

30. Rhaleb NE, Rouissi N, Jukic D, Regoli D, Henke S, Breipohl G, and Knolle J. Pharmacological characterization of a new highly potent $\mathrm{B}_{2}$ receptor antagonist [HOE 140: D-Arg(Hyp3, Thi5, D-Tic7, Qic8)bradykinin]. Eur J Pharmacol 210: 115-120, 1992.

31. Rosenthal JH, Pfeifle B, Michailov ML, Pschorr J, Jacob IC, and Dahlheim H. Investigations of components of the renin-angiotensin system in rat vascular tissue. Hypertension 6: 383-390, 1984.

32. Siegel G, Walter A, Schnalke F, Schmidt Buddecke E, Loirand G, and Stock G. Potassium channel activation, hyperpolarization, and vascular relaxation. $Z$ Kardiol 80, Suppl 7: 9-24, 1991.

33. Vincent PA, Adler C, Avila C, Guardia DC, and De Vito E. Prorenins activation by an enzyme from rat plasma (PreR-Co). Comp Biochem Physiol B Biochem Mol Biol 131: 201-207, 2002.

34. Vincent PA and De Vito E. Rat renal and plasma prorenin are activated in vitro by different mechanisms. Hypertension 34: 520-524, 1999.

35. Yanagisawa M, Kurihara H, Kimura S, Tomobe Y, Kobayashi M, Mitsui Y, Yazaki Y, Goto K, and Masaki T. A novel potent vasoconstrictor peptide produced by vascular endothelial cells. Nature 332: 411-415, 1988. 